\title{
研究のスボット リンゴのミツ症状
}

福田博之

農林水産省果樹試験場盛岡支場

ミッ症状は，成熟期に達した果害内部で一部の組織が 水浸状になる現象である. 果心 (core) 部から水浸状に なることが多いので, 英語では watercore と称されてい る(図 1). 、ツ症状が発生した果実は特有の発醉臭が発 生するが，欧米ではこれを好まない人が多く，一種の生 理障害之考党られている.しかし，日本人はむしるこの 発酵臭を好む傾向があり「らじ」や「スターキング」な どの品種ではミツ症状の発生した果実が“ミッ入りリン ゴ”と称し，高值で取り引きされている.

特に, 収穫直後の 10 月下旬から 12 月末までは, こ れらの品種でミッ入りが認められない果実は食味が劣る ので，ミッ症状は果実品質のメルクマールにるなってい る. ミッ症状は樹上での登生が進み, 早期に収檴した 果実を後熟させても発生しないので，ミッ入りはリンゴ を樹上で完熟させた証拠にもなる。

一方，ミッ入りリンゴを好まないアメリカでは，「デ リシャス」は末だ末熟な 9 月に収穫される。このような リンゴは, デンプンがまだ大量に残っており, 粉っぽい

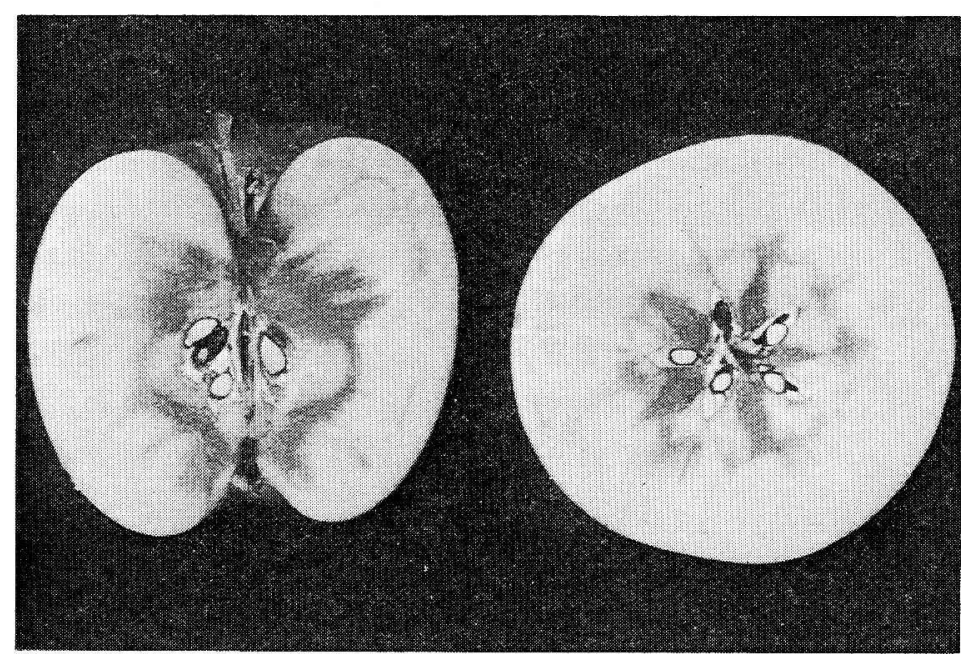

図1-「ふじ」のミツ症状
味がしてすぐには食べられない，貯蔵中にデンプンが糖 化して 3，4月ごろになってはじめて味がよくなる.ア ×リカでは,「デリシャス」は翌年の 7,8 月になっても 売られており，長期貯蔵が可能な品種とされている. 乙 かし、ミッ症状が発生してから收檴するかが国では, こ の品種はせいぜい 2,3 月までしか唄蔵できない，果肉 の軟化が著しくなるだけでなく，後述のように果肉の内 部褐变が発生するためである。

なお，「つがる」「陸奥」や古い品種の「印度」など で，8月ごろに果肉の一部が同様に水浸状になることが ある.これを早期ミッ (early watercore) として収穫期 のミッスりとは区別することがある. 早期ミッは夏の高 温によって果肉組織に異常が生じるためとされ，外国で はミッ発生部位が裼変することが報告されているが，か， が国では收穫期までに水浸部位が痕跡を残さず消失し， まったく実害が認められない、したがって，本稿では主 として収穫期のミッ症状について論ずることにする。

\section{㷌ミツ症状の発生状況鹿}

収穫期のミツ症状は，一般に果肉: 部と果心部を分ける果心線の部分か ら発生する（図1)。果心線は形態 学的には，がく維管束和よび花升維 管束であり，果柄を通じて果実内に 入ってきた養分がこ机らの維管束か ら果肉組織へ供給されると考えられ る.この果心線のまわりに発生した ミッ症状浊, 樹上での成熟が進もに つれて果肉部をたは果心部へと広が る.

その広がり方は品種によって差異 があり「ふじ」や「王林」などで 
は果心内が主であるのに対し，「デリシャス」や「レッ ドゴールド」，「紅玉」などの品種は果肉部への広がりが 著しい，一万，ミツ症状がほとえど発生しない品種もあ り「ゴールデンデりシャス」,「つがる」,「陸奥」など では，樹上で完熟させてもミッ症状が認められることは きわめて希である。

ミッ症状で水浸状になった組織は淡い黄色または黄緑 色を呈し，まわりの白色の組織と明確に区別できる（図 1). まわりの果肉組織が白くみえるのは, 細胞間隙に 含まれている空気により光が乱反射するためである，果 肉を煮るなどの方法で細胞間隙の空気を追い出すとミッ 症状と同様に全体が黄色くなる。

ミツ症状で水浸状になった果実組織では細胞間隙まで 水分で満たされ, 光の乱反射がなくなるので透き通って み觉る. 組織が光をよく通すようになるので, 後述する 光の透過度による非破壞的なミッ入り程度の測定も可能 になる。

ミツ症状は原則として樹上だけで発達する，収穫後に は次第に消失するだけで，冷蔵庫内でも「ふじ」や「デ リシャス」のミッ症状は1月中旬にはほとんどなくな る. しかし，ミッ入り果実はその後に果肉の内部褐变が 発生することがあるので, 収穫後できるだけ早く販売し なければならない。

ミッ症状の発生はすべての果実に一斉に起こるもので はない、収穫した果実にはミッ症状のないるのから果肉 のかなりの部分に広がっているものまで, 発生程度が種 種に異なるものが含まれている。これを区分できればよ いのであるが，ミッ症状は果実の内部に発生するので， 外から見ただけでは明磪に判定できない，この問題を解 決するため，非破壊的に果実を切断せずにミツ症状の発 生程度を区分する方法がいくつか提案されている.

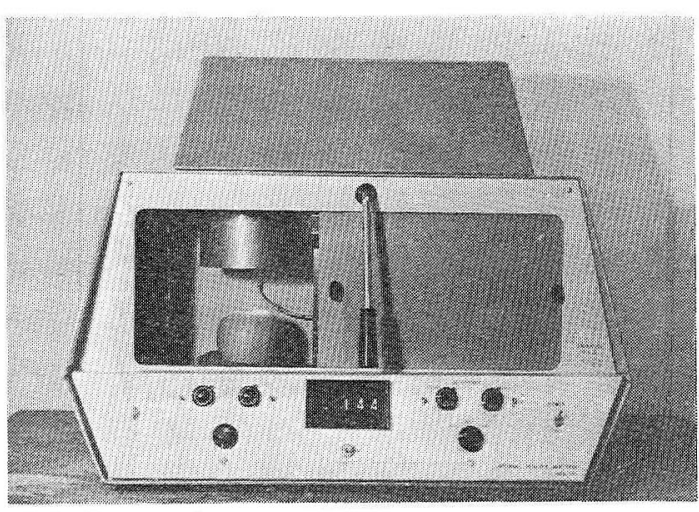

図 2 Internal quality analyzer

ッ入り果実より比重が高くなることを利用している．収 穫直後に，適当な割合でアルコールなどを混ぜて比重を 低くした水溶液に果実を漬けると，比重の高いミッ入り 果実は沈むのに対して, 非ミッ入り果実は水面に浮くの で区別できる，しかし，ミッ発生程度を細かく区分する ことは難しい。

これに対し, (2)の方法は発生程度を比較的細かく区分 できる.この方法は果実に近赤外線を透過させてその透 過度を測定するもので, internal quality analyzer と呼 ばれる測定機がアィリカで開発されている(図 2).

湘定法は原理的に二つに分けられる. 一つは果実の水 分含有量が増加することから，水の吸収波長 $(760 \mathrm{~nm})$ と吸収されない波長 $(810 \mathrm{~nm})$ を用いて，その透過量の 差異值 $\triangle \mathrm{OD}(760 \mathrm{~nm}-810 \mathrm{~nm})$ によってミッ発生程 度を判定するものである. 一種のダブルビーム比色法で ある.この方法によってかなり正確にミッ発生程度が測 定できるが, 透過量の差異值がきわめて小さいので（表 1), 精度の高い測定機を必要とする. また, $760 \mathrm{~nm} の$ 透 過量が果実温度の影響を受けるため, 温度を一定にして 測定を行なわなければならない、的。

\section{叫症状の非破壊的測定乣}

非破壊的測定法はいずれもまだ選 果場で使用できるまでにはなってい ないが，実験室でのミッ症状測定が できるむのとして，ここでは，(1)比 重による方法と, (2)光の透過による 方法について述べることにする.

(1)の方法は，ミッ入り果実では細 胞間隙が水で満たされるので, 非ミ
表 1 四「デリシャス」のミッ発生程度と光透過度 (OD) 值との関係（ダブル ビーム法とシングルビーム法の比較)

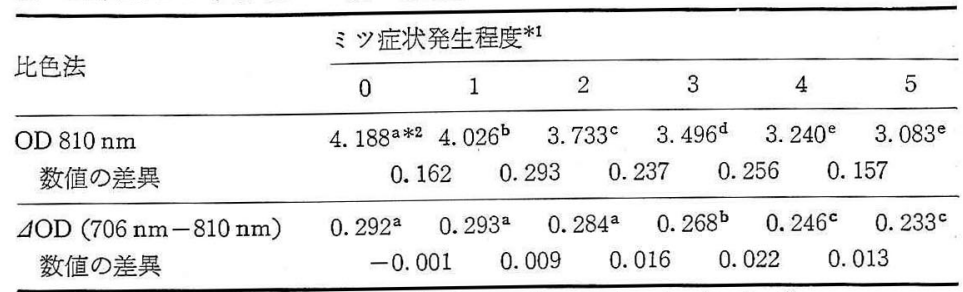

*1ミツ症状発生程度 $0:$ なし， $1:$ 痕跡，3:少，3:中，4:大，5:甚 *2 ダンカン法による有意差検定 ( $5 \%$ 水準). $\mathrm{a}, \mathrm{b}, \mathrm{c}, \cdots$ の記号が異なるものの閒には有 意差あり. 
もら一つは，水浸状の組織が光をよく透過させること を利用するもので，この場合，温度の影響を受けない $810 \mathrm{~nm}$ の単波長を透過させ，その透過量 OD $810 \mathrm{~nm}$ の 大きさによってミッ発生程度を測定する.いわばシング ルビームの比色法であるが，透過量の差異值によるダブ ルビーム法より数值が大きく, 測定も楽である(2).

表 1 はこれら 2 つの透過法を比較したものである.シ ングルビーム法では発生程度 0 から 2 の比較的軽度のミ ッ入り果を鋭敏に区分できることが認められる，一方， ダブルビーム法ではミッ発生程度 0 ～2では数值に有意 な差異がなく，区分ができなかった、シングルビーム法 は果実温度の影響を受けないだけでなく，果実の大きさ の影響もそれ注問題にならないようである(1,2).

\section{Vミツ症状の発生機構仿}

果実組織の一部が水浸状になることはミツ症状だけで なく, ある種の病菌によって果害が腐敗したときや, 班 点性生理障害の一種であるコルクスポットの発生直前な ぞにも認められる. この場合の水浸状化虫, 細胞膜組織 が何らかの障害を受けるためであると考皃られる. 前述 の早期ミッの場合も，果肉組織が高温で障害を受けたこ とが関係するとされている，早期ミッは特に袋掛けをし た果実に多いが，袋内の温度は外気温よりかなり高くな っている. では, 収穫期に発生するミッ入り果実ではど うであろらか。

家庭用ジューサーを用いてミッ入り果実から絞ったジ

表 2・リンゴ品種「ワインサップ」のミツ発生果および 非発生果の果汁中に含まれる糖成分の組成 (Williams, 1966)

\begin{tabular}{|c|c|c|c|c|c|c|}
\hline \multirow{2}{*}{\multicolumn{2}{|c|}{ 果実の区分 }} & \multicolumn{4}{|c|}{ 糖含有量 $(\mathrm{mg} / \mathrm{ml})$} & \multirow{2}{*}{$\begin{array}{l}\text { 属折計 } \\
\text { 蔗 }\end{array}$} \\
\hline & & $\begin{array}{l}\text { スクロ } \\
\text { スー }\end{array}$ & $\begin{array}{l}\text { グルニ } \\
-\pi\end{array}$ & $\begin{array}{l}\text { フルルク } \\
\text { トース }\end{array}$ & $\begin{array}{l}\text { ソルビ } \\
\text { トール }\end{array}$ & \\
\hline \multirow[t]{3}{*}{ 発生果 } & ミッ部分 & 38 & 37 & 30 & 18 & 13.7 \\
\hline & 非ミツ部分 & 41 & 42 & 34 & 13 & 14.4 \\
\hline & $\begin{array}{l}\text { 果心部に溢 } \\
\text { 出した果汁 }\end{array}$ & 18 & 7 & 6 & 48 & 8.0 \\
\hline \multicolumn{2}{|c|}{ 非発生果 } & 38 & 40 & 32 & 9 & 13. 9 \\
\hline
\end{tabular}

ニースを東洋 No.1 あるいは No. 2 の濾紙で漉すと, 著 しく濾過速度が遅くなることが認められている，滤過速 度はミッ症状の発生が著しい果実注ぞ遅くなる傾向があ る. 一方,「ゴールデンデリシャス」など, ミッ症状の発 生がない品種では，樹上で完熟した果実でも濾過の遅れ はほとんどない：シッ入り果実の濾過の遅れは, 細胞膜 質が分解してコロイド化し，濾紙の細かい穴を埋めてし まうためと考觉られるが，この物質が何かはまだ同定さ れていない。

細胞膜質以外の変化としては, ミッ発生果実には糖ア ルコールの一種であるソルビトールの含有量が高まって いることが認められている(表 2). 一方, ミッ発生のな い「ゴールデンデリシャス」では成熟期にもこの糖アル コールの増加はさわめて少ない(3).これらのことから， 果実内でのソルビトールの集積が何らかの形でミッ症状 の発生に関与していると考党られている.

果実の糖分は葉から主としてふるい管を通して供給さ れるが，その場合，リンゴではほとんぞソルビトールの 形をとるとされている．表 3 は，移動中の糖の組成を明 らかにするため，その通路に当たる葉柄，および果柄の 糖を分析した結果である. 分析はミッ発生前の 9 月 10 日と発生後の 10 月 9 日飞行なっているが，いずれも 80\% 以上がンルビトールとなっている，果柄から果実 内に入ったソルビトールは果心線などを通って果肉細胞 に供給される. 未熟な果実では, 細胞内に入ったソルビ トールはフルクトースなどに転化され，液胞内に貯蔵さ れる. しかし、「デリシャス」などミッ症状の発生する品 種では，成熟が進むに従ってソルビトールを他の糖に転 化する能力が低下し，その結果，果実内にソルビトール が集積すると考えられている.

フルクトースなどの糖類は細胞の液胞内に蓄えられる のに対し，ソルビトールは細胞膜を透過する性質が強 く, 細胞の外に浸出しやすい, ${ }^{(4)}$ 成熟之ともに果実内に ソルビトールが集積すると，かなりの部分は細胞間隙に 浸出する．表 2 に示した果心部に溢出した果汁はそれに 当たるが，ソルビトールの割合が著

表 3ロ「デリシャス」の葉柄および果柄中の糖成分組成 (Kollas, 1968)

\begin{tabular}{|c|c|c|c|c|c|c|c|c|}
\hline \multirow[b]{2}{*}{ 調査日 } & \multicolumn{4}{|c|}{ 葉柄 $(\%)$} & \multicolumn{4}{|c|}{ 果柄 $(\%)$} \\
\hline & $\begin{array}{l}\text { スクロ } \\
\text { ース }\end{array}$ & $\begin{array}{l}\text { グルニ } \\
\text { ース }\end{array}$ & $\begin{array}{l}\text { フルク } \\
\text { トース }\end{array}$ & $\begin{array}{l}\text { ソルビ } \\
\text { トール }\end{array}$ & $\begin{array}{l}\text { スクロ } \\
\text { ース }\end{array}$ & $\begin{array}{l}\text { グル= } \\
\text { ース }\end{array}$ & $\begin{array}{l}\text { フルク } \\
\text { トース }\end{array}$ & $\begin{array}{l}\text { ソルビ } \\
\text { トール }\end{array}$ \\
\hline 9 月 10 日 & 1.3 & 7.2 & 6.9 & 84.5 & 6.9 & 5.8 & 6.0 & 81.3 \\
\hline 10 月 9 日 & 2.4 & 4.9 & 4.5 & 88.1 & 7.3 & 4.0 & 2.6 & 86.1 \\
\hline
\end{tabular}
しく高まっている.これらの事実か ら，ソルビトールは細胞間隙の浸透 圧を高め，周团の組織から水分を吸 引するので間隙が水浸状になりミッ 症状が発生する，といらのがミッ症 
表 4ロ霜害により凍結した「ふじ」のミツ症状発生と品 質 (工藤ら，1983）

\begin{tabular}{|c|c|c|c|c|c|}
\hline 果実の区分 & $\begin{array}{c}1 \text { 果重 } \\
(\mathrm{g})\end{array}$ & $\begin{array}{l}\text { ミッ入り } \\
\text { 示度 }\end{array}$ & $\begin{array}{l}\text { 果肉硬度 } \\
\text { (ポソド) }\end{array}$ & $\begin{array}{l}\text { 風折計示 } \\
\text { 度 }(\%)\end{array}$ & (酸) \\
\hline 凍結後 & 266 & 2.6 & 15.2 & 14.1 & 0.47 \\
\hline 凍結前 & 259 & 1.7 & 16.3 & 14.4 & 0.49 \\
\hline 有意性 & ns & * & $* *$ & $\mathrm{~ns}$ & ns \\
\hline
\end{tabular}

$*: 5 \%$ 水準で有意差あり, $* *: 1 \%$ 水準で有意差あり $\mathrm{ns}$ : 有意差なし

状発生に関する有力な仮説とされている.

しかし，浸透压だけで説明できるかどらか疑問もあ る. 前述のように, 細胞膜物質が分解し膜の透過性が変 化することも考えられる. この点について, 収穫期のミ ツ症状に関しても，霜害をらけた果実に拈いて凍結の前 後わずか 36 時間のあいだに発生程度が著しく増加した 事例も認められている(表 4).これは，霜害が細胞膜質 に変化を与えたためと考えられる.

\section{Wミツ症状と内部褐変との関係统}

「デリシャス」のミッ入り果実を長期貯蔵すると，果 心線周辺の果肉が褐変する生理障害が発生する.この障 害は果肉の内層部に発生するので内部褐変と呼ばれてい る. 図 3 は, 収穫直後に前述のダブルビームおよびシン グルビーム比色法でミッ入り程度を測定した「デリシャ ス」について, 貯蔵後の内部褐変の発生を調査したもの である・

ダブルビーム法で 0.28 以下， シングルビーム法で 3.7 以下の果実は厌とんどが内部褐変に侵されているこ とがわかる、この数值は, 表 1 によるとミッ発生程度が 1 ないし 2 以上の果実に当たり，ごくわずかでもミッ症 状の発生した果実は貯蔵中に内部褐変に侵される可能性 を示している．内部褐変は「ふじ」でも発生するが，発 生率は「デリシャス」より低い「「デリシャス」ではミッ 症状が果肉に広がりやすいのに対し，「ふじ」のミッ症 状は果心部を中心に広がることが関係しているのかもし れない.な拉,「デリシャス」のミッ症状は普通, 1 月中 旬には汷とんど消失してしまうのに，内部褐変の発生は 3 月になってから増加する傾向がある. ミッ症状の消失 から内部褐変の発生まで若干の時間的なずれがあり, し たがって組織の水浸状化がこの生理障書の直接的な原因 とは考光にくい.

果肉組織が褐変するのは，液胞に含まれたフェノール 物質が酵素の働きで酸化されるためと考えられる．酵素

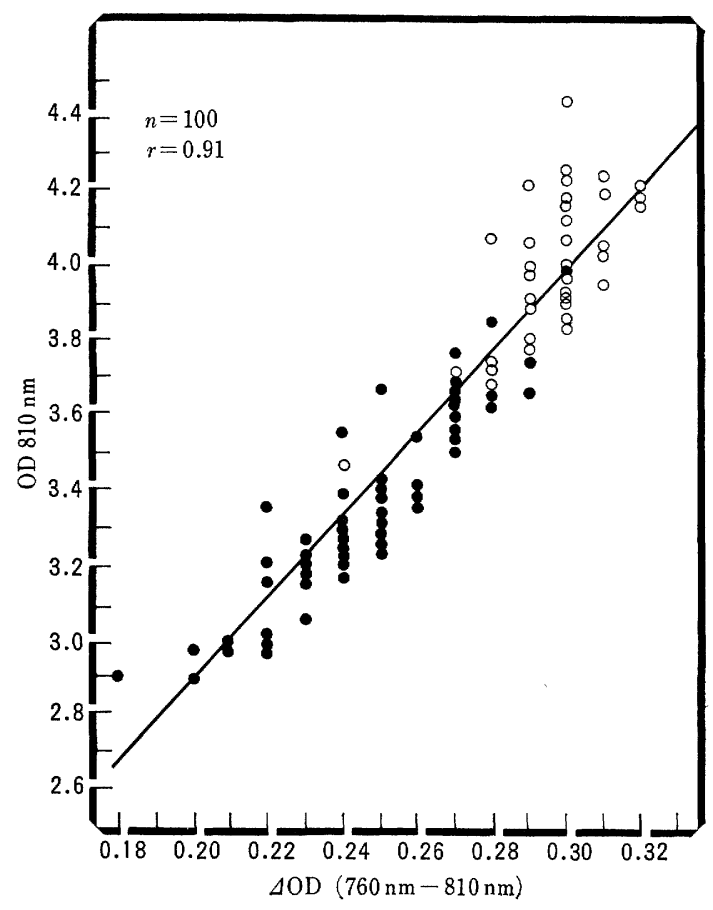

図 3 -収穫直後のミツ発生程度亡内部褐変発生亡の関係

・：内部褐変に侵されている果実，○：健全果

は普通, 細胞の原形質部分に存在していると考えられる ので, フェノール物質の酸化には液胞と原形質の間の膜 の透過性が変化し，これらの物質と酵素が一緒になる必 要がある. この点, 樹上でミッ症状の発生した果実は, 前述のように膜質が変化している可能性が高い，貯蔵中 での果肉組織の老化によってさらに膜質の透過性が変化 して果肉の褐変に結びつくことが考えられる.

一方, アメリカのように 9 月に未熟な状態で収穫した 場合には, 翌年の 7,8 月まで貯蔵しても内部褐変の発 生はきわめて少ない。この場合と, ミッ発生の後に収穫 した場合とでは, 貯蔵中の果肉の老化の過程が異なると 考克られる.な和, ソルビトールと内部褐变発生との関 係については，これまで有力な仮説は提出されていない が，この糖アルコールが膜質の透過性に影響を与えるこ とも考光られる。

\section{"ミッツ症状発生の人為的コントロール /}

ミッ症状の発生を抑制するには, 着果量を多くして果 実当たりの葉枚数を少なくするとよいまた，「デリシ ヤス」には 9 月の未熟段階にもすでにきわめてよい着色 をする突然変異系統が多数発見されているが，これらの 
表 5 落果防止剂 2,4 DP の散布が「デリシャス」品質 に及ばす影響 (1981)

\begin{tabular}{|c|c|c|c|c|c|}
\hline \multicolumn{2}{|c|}{ 散布処理 } & \multirow{2}{*}{$\begin{array}{l}\begin{array}{l}\text { ミ喾症状 } \\
\text { 程度 }\end{array} \\
3.5^{\mathrm{a}}\end{array}$} & \multirow{2}{*}{$\frac{\begin{array}{l}\text { 果肉硬度 } \\
(\text { ポソド) }\end{array}}{15.6^{\mathrm{ab}}}$} & \multirow{2}{*}{$\begin{array}{l}\begin{array}{l}\text { 属折計示 } \\
\text { 度 }(\%)\end{array} \\
12.9^{\mathrm{a}}\end{array}$} & \multirow{2}{*}{$\frac{\begin{array}{c}\text { 酸含有量 } \\
(\%)\end{array}}{0.31^{\mathrm{a}}}$} \\
\hline $2,4 \mathrm{DP}$ & $30 \mathrm{ppm}$ & & & & \\
\hline & $45 \mathrm{ppm}$ & $3.7^{\mathrm{a}}$ & $15.9^{a}$ & $13.0^{\mathrm{a}}$ & $0.32^{\mathrm{a}}$ \\
\hline 対照 & & $2.5^{\mathrm{b}}$ & $15.3^{b}$ & $12.1^{\mathrm{b}}$ & $0.31^{\mathrm{a}}$ \\
\hline
\end{tabular}

a,b : 表 1 の注参照

系統は一般にミッ症状の発生が少ない. リンゴの赤色色 素アントシアニンの形成に糖が使用されるためとも考学 られる、このためアメリカでは，これら着色系統を用 い, 摘果をせずに着果量を多くしてこの品種の栽培が行 なわれている，また，B-9 や PP-333 などの生育抑制剤 は果実の成熟を遅らせミッ発生を抑制する効果が認めら れているので，その実用化が検討されている.

一方，わが国ではむしろ発生を促進する方法のほうに 関心が高い: ミッ発生を促進する方法としては，オーキ シンやェチレンを成熟直前に散布すると効果が大きい,

特に，オーキシンは収穫前落果を防止する効果があるの で，わが国では落果防止を第一の目的として広く使用さ れてきた. 表 5 はオーキシン郕の一つである $2,4 \mathrm{DP} に$ よるミツ症状扣よび果実品質に詨する効果を示してい る.またエチレンの効果はオーキシンよりむしろ高い が，このホルモンは落果を促進するのでわが国ではほと んど使用されていない.
エチレンについては，これまです成熟促進ホルモンと して成熟を早める働さを持っていることが明らかにされ ている，したがって，エチレンを処理した果実は成熟が 進み,ソルビトールをフルクトースなどに変換する果肉 組織の能力が低下し，ソルビトールが果実内で集積する ことが考えられる.なお，前述の生育抑制剤はェチレン の生成を遅らせることが明らかになっている。

また，オーキシンについても，ミッ発生促進の他，リ ンゴの着色増進, 糖の増加促進など, 若干の成熟促進作 用のあることが認められている(6). その作用機構拉よび エチレンとの関係は明らかでないが，いずれにしてもそ の成熟促進作用は，成熟関係する各種酵素の形成ある いは活性促進によってなされるるのと思われる．酵素の 動態, 特にミッ発生との関係については, 今後の検討が 待たれる。

1）福田博之, 久保田貞三, 巣山太郎 : 果樹試報 C 6, 1979, p. 27.

2）福田博之, 久保田貞三 : 果樹試報 C 15，1988， p. 41.

3) M. W. Williams : Proc. Amer. Soc. Hort.Sci., 88, 76, 1966.

4) D. A. Kollas : "Physiology of Watercore Development in Apple", Ph.D. Thesis, Cornell Univ., 1968.

5）工藤和典, 樫村芳記, 福田博之, 西山保直 : 昭和 58 年度園 芸学会東北支部会発表要旨, 1983, p. 33 .

6) 福田博之, 工藤和典, 樫村芳記, 滝下文孝, 增田哲男, 西山 保直：果樹試報 C $12 ， 1985$, p. 53 .

\section{化学と生物}

Vol.27, No.5 (306 号)

1989 年 5 月 25 日発行 (月刊) 定価 760 円（本体 738 円）

編集者・社団法人 日本農芸化学会 発行者・株式会社 学会出版センター 113 東京都文京区本楖 6-2-10 印刷者・新日本印刷株式会社 㨉図・伊藤 允三 装幀・万膳 寛

\section{- 企画委員会}

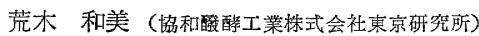
池庄司敏明 (東京大学農学部農業生物学科) 石塚 潤爾 (九州大学農学部農芸化学科) 一島 英治 (東北大学農学部農芸化学科) 江原 淑夫 (東北大学農学部農学科) 大久保昭行 (東京大学医学部中央検查部) 大山 勝夫 (農林水産省生物資源研究所) 岡村 圭造 (京都大学農学部林産工学科) 小野寺一清 (東京大学農学部農芸化学科) 葛西 隆則 (北海道大学農学部農芸化学科) 上原悌次郎 (京都大学工学部工業化学科) 川西 悟生 (雪印乳業株式会社生物科学研究所) 向阪 正信 (藤沢薬品工業株式会社筑波研究所) 小泉 千秋 (東京水産大学水産学部食品生産学科) 小林 彰夫（扣茶の水女子大学家政学部食物学科） 金野 隆光 (農林水産省四国農業試験場) 榊原 祥公 (国立予防衛生研究所)
匂坂勝之助 (北海道大学低温科学研究所) 柴井博四郎 (味の素梾式会社中央研究所) 首藤 紘一 (東京大学薬学部菂学科) 杉山 達夫 (名古屋大学農学部農芸化学科) 高野 光男 (大阪大学工学部醴醉工学科) 外村辨一郎 (京都大学農学部食品工学科) 富田 武 (名古屋大学農学部畜産学科) 船津 軍喜 (九州大学農学部䟴芸化学科) 真 鍋 勝 (農林水産省食品総合研究所) 室 伏 旭 (東京大学農学部農芸化学科) 安 元 健 (東北大学農学部農芸化学科) 吉岡 宏輔 (理化学研究所) 企画委員長 矢野 圭司（東京大学農学部農芸化学科） 企画理事

魚住 武司（東京大学農学部灾用生命工学専坟） 小川 智也（理化学研究所） 